\title{
Chylothorax due to enlarged tuberculous lymph nodes
}

\author{
Silvia Bielsa, ${ }^{1}$ Marina Pardina, ${ }^{2}$ José M Porcel ${ }^{1}$
}

${ }^{1}$ Department of Internal Medicine, Arnau de Vilanova University Hospital, Lleida, Spain

${ }^{2}$ Department of Radiology, Arnau de Vilanova University Hospital, Lleida, Spain

\section{Correspondence to} Dr Silvia Bielsa, silviabmartn@hotmail.com

Accepted 18 April 2014
CrossMark

To cite: Bielsa $\mathrm{S}$,

Pardina M, Porcel JM. BMJ Case Rep Published online: [please include Day Month Year] doi:10.1136/bcr-2014204582

\section{DESCRIPTION}

A 37-year-old man was evaluated for a 2-month history of fever, cough and weight loss. He was diagnosed with AIDS 3 years ago, had a recent CD4 cells count of $199 / \mu \mathrm{L}$ and was receiving antiretroviral therapy. Physical examination revealed decreased breath sounds and dullness to percussion on the left base. Chest radiograph showed a moderate sized left pleural effusion. Thoracentesis yielded a milky fluid with a leucocyte count of 792 cells/ $\mu \mathrm{L}$ (94\% lymphocytes), total protein $5.4 \mathrm{~g} / \mathrm{dL}$ (serum $6.4 \mathrm{~g} / \mathrm{dL}$ ), lactate dehydrogenase 347 IU/L (serum 875 IU/L), glucose $112 \mathrm{mg} / \mathrm{dL}$, adenosine deaminase $48 \mathrm{IU} / \mathrm{L}$, cholesterol $72 \mathrm{mg} / \mathrm{dL}$ (serum $102 \mathrm{mg} / \mathrm{dL}$ ) and triglycerides $281 \mathrm{mg} / \mathrm{dL}$ (serum $83 \mathrm{mg} / \mathrm{dL}$ ). Results of pleural fluid and sputum smears and cultures for mycobacteria were negative. CT revealed a left pleural effusion and a diffuse miliary pattern (figure 1A). A retrocrural enlarged lymph node compressing the cisterna chyli along with a dilated thoracic duct was also noted (figure 2). These radiological signs cleared after 6 months of antituberculous therapy (figure 1B).

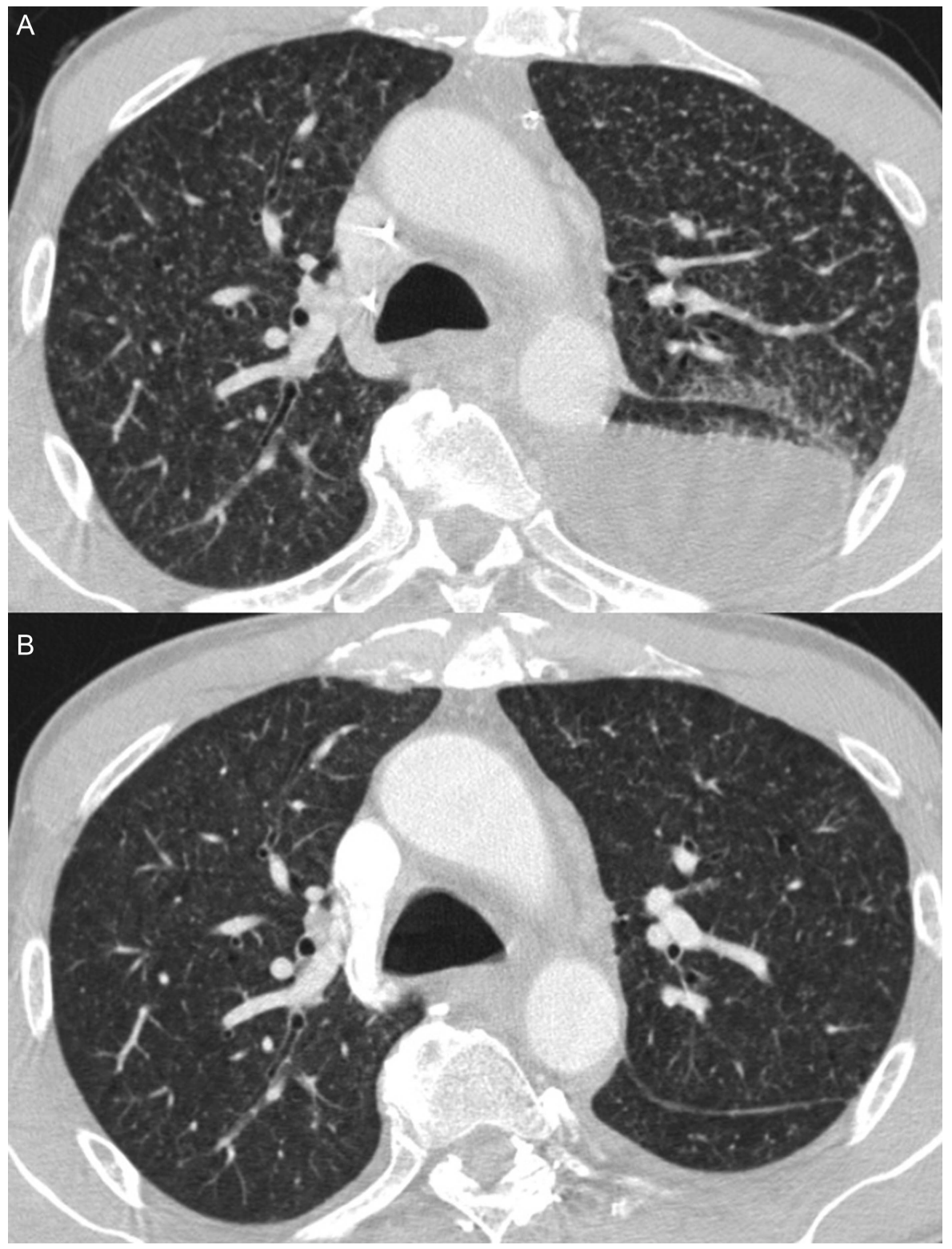

Figure 1 CT showing a left pleural effusion and numerous small lung nodules diffusely distributed (A), with resolution after 6 months of antituberculous treatment (B). 


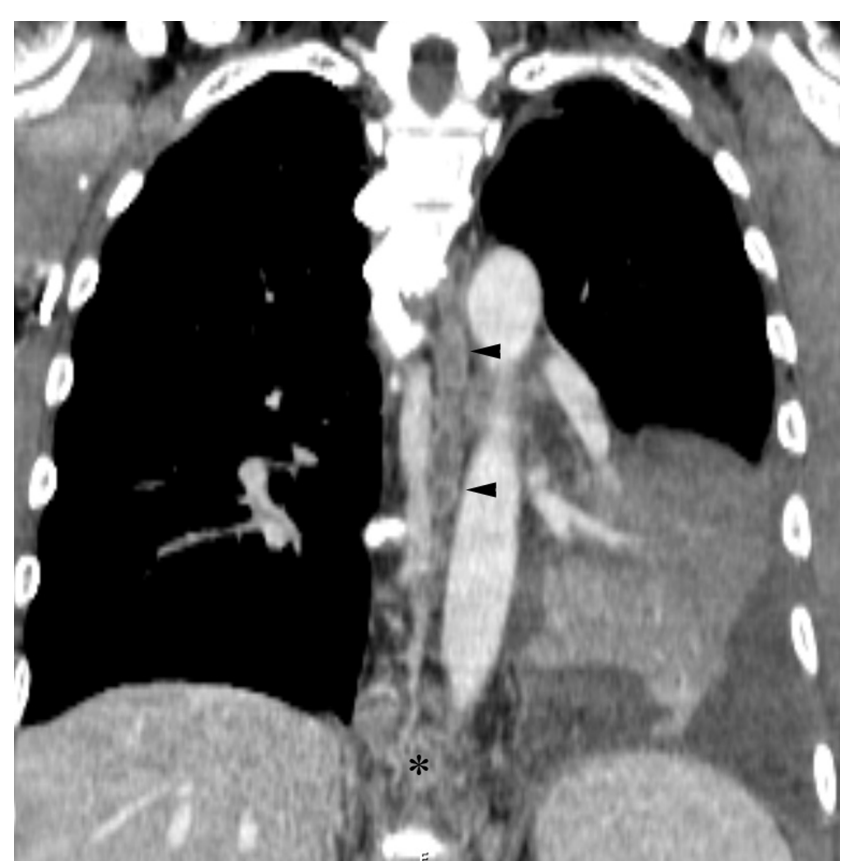

Figure 2 CT demonstrating an enlarged retrocrural lymph node which compresses the cisterna chyli (arterisk), along with a dilated thoracic duct (arrowheads).

\section{Learning points}

- Tuberculous chylothorax is a rare condition, with only anecdotal cases being reported in literature. ${ }^{1}$

- Occasionally, thoracic duct obstruction leading to the leakage of chyle into the pleural space may result from tuberculous mediastinal lymph nodes. ${ }^{2}$

- Anti-tuberculous therapy along with therapeutic thoracenteses usually solve the chylothorax.

Contributors Drafting of the article: SB. Interpretation of the data and images: SB, MP, JMP. Preparation of images: MP. Final approval of the article: SB, MP, JMP.

Competing interests None.

Patient consent Obtained.

Provenance and peer review Not commissioned; externally peer reviewed.

\section{REFERENCES}

1 Anton PA, Rubio J, Casán P, et al. Chylothorax due to Mycobacterium tuberculosis. Thorax 1995;50:1019.

2 Karapolat S, Sanli A, Onen A. Chylothorax due to tuberculosis lymphadenopathy: report of a case. Surg Today 2008;38:938-41.

Copyright 2014 BMJ Publishing Group. All rights reserved. For permission to reuse any of this content visit

http://group.bmj.com/group/rights-licensing/permissions.

BMJ Case Report Fellows may re-use this article for personal use and teaching without any further permission.

Become a Fellow of BMJ Case Reports today and you can:

- Submit as many cases as you like

- Enjoy fast sympathetic peer review and rapid publication of accepted articles

- Access all the published articles

- Re-use any of the published material for personal use and teaching without further permission

For information on Institutional Fellowships contact consortiasales@bmjgroup.com

Visit casereports.bmj.com for more articles like this and to become a Fellow 